\title{
Judicial Review and the War on Terrorism
}

\author{
John C. Yoo*
}

\section{Introduction}

Nowhere do academic arguments and government practice deviate more sharply than on the question of judicial review of war powers. Throughout our history, presidents and Congresses have struggled over the constitutional authority to initiate military hostilities. Generally, the federal courts have refused to address this question on the merits, with the result that presidents often have intervened abroad without a declaration of war or other authorization from Congress. The recent wars in Afghanistan and Iraq, in which Congress enacted statutes authorizing the use of force, may be the exceptions that prove the rule. In Kosovo, Bosnia, Haiti, Somalia, the Persian Gulf, Grenada, Lebanon, and Korea, to name but a few, presidents have ordered the use of force unilaterally, without congressional authorization or a declaration of war. ${ }^{1}$

Academics almost uniformly criticize the president's current primacy in war powers. They argue that Congress's power to declare war requires that the president receive a declaration of war or other statutory authorization before using force abroad. ${ }^{2}$ Despite their claims that much presidential war making has been unconstitutional, academics have reserved their sharpest attacks for the judiciary, which they have accused of "hypocrisy" for refusing to exercise judicial review over war-powers questions. ${ }^{3}$ The basic claim is straightforward: Marbury $v$. Madison ${ }^{4}$ does not create an exception from judicial review for war powers. At times, scholars have even taken the more

* Visiting Professor of Law, University of Chicago Law School; Professor of Law, University of California at Berkeley School of Law (Boalt Hall) (on leave); Visiting Fellow, American Enterprise Institute. I thank Jesse Choper, Brad Clark, Robert Delahunty, Jack Goldsmith, Cass Sunstein, and Adrian Vermeule for their helpful comments.

1 John C. Yoo, Kosovo, War Powers, and the Multilateral Future, 148 U. PA. L. REV. 1673, 1673-74 (2000) [hereinafter Yoo, Kosovo]; John C. Yoo, The Continuation of Politics by Other Means: The Original Understanding of War Powers, 84 CAL. L. REv. 167, 170 (1996) [hereinafter Yoo, Continuation of Politics].

2 See, e.g., John Hart Ely, War and Responsibility: Constitutional Lessons of Vietnam and Its Aftermath 3 (1993); Louis Fisher, Presidential War Power 203 (1995); Michael J. Glennon, Constitutional Diplomacy 81 (1990); Harold Honguu Koh, The National Security Constitution: Sharing Power After the Iran-Contra Affair 158-61 (1990); Michael D. Ramsey, Textualism and War Powers, 69 U. CHI. L. Rev. 1543, 1548 (2002); William Michael Treanor, Fame, the Founding, and the Power to Declare War, 82 CoR. NELL L. Rev. 695, 700 (1997).

3 See, e.g., Thomas M. Franck, Political Questions/Judicial Answers: Does the Rule of Law Apply to Foreign Affairs? 30 (1992).

4 Marbury v. Madison, 5 U.S. (1 Cranch) 137 (1803).

December 2003 Vol. 72 No. $1 / 2$ 
direct approach of supporting lawsuits against presidential use of force and urging the courts to enjoin hostilities until Congress has given its approval. ${ }^{5}$

In my earlier criticism of the conventional wisdom, I have argued that the Constitution creates a flexible system for going to war, in which the president can initiate hostilities unilaterally, subject to congressional funding. ${ }^{6}$ In that work, I have argued that the Constitution does not provide the courts with a role in the decision to wage war; it textually allocates that power to the political branches. As is evident elsewhere in this symposium, however, in a separate work I have also argued that Marbury $v$. Madison correctly interpreted the Constitution as allowing the federal courts to refuse to enforce unconstitutional laws, the practice we know today as judicial review.?

In this essay, I explain that the exclusion of the federal courts from the question of war initiation is consistent with judicial review. The Constitution does not give the federal courts a role in reviewing the initiation of hostilities because it has directly vested the authority to make that decision in the political branches. By giving to Congress the power to "declare War," the Constitution has vested the legislature, rather than the courts, with the juridical power to determine the legal status of a conflict with another nation. Further, the Constitution does not create any specific process for going to war, unlike enacting statutes, making treaties, or appointing officers. Rather, the Constitution allocates different war powers to the president and Congress, allowing them to shape war making through the interaction of these powers. There is no role for judicial review because there is no single, constitutionally-required process for making war. This view has been borne out in practice, as most recently demonstrated in the wars in Afghanistan and Iraq.

This is not to say, however, that the courts are completely ousted from any case involving war. Federal courts still have a role to play with regard to the domestic effects of war, particularly when the war involves American citizens as enemies or when operations occur within the territory of the United States itself. Part III of this paper illustrates the wartime role of judicial review by examining cases arising from the current war against the al Qaeda terrorist organization. In the context of surveillance, the federal courts have granted warrants under the Foreign Intelligence Surveillance Act ("FISA"), ${ }^{8}$ under more flexible standards than exist for a normal search warrant, to permit surveillance of terrorist suspects. With American citizens detained as enemy combatants, the courts have entertained habeas corpus petitions, but have followed a deferential standard of scrutiny for the executive branch's war-making decisions. These cases show that while the courts have exercised judicial review over the consequences of the decision to go to war, they have adopted a more flexible, deferential standard of review than would apply to normal, peacetime governmental actions, in order to accommodate the im-

5 See John C. Yoo, The Dogs That Didn't Bark: Why Were International Legal Scholars MIA on Kosovo?, 1 CHI. J. INT'L L. 149, 150 (2000).

6 My textual and structural arguments may be found in John C. Yoo, War and the Constitutional Text, 69 U. CHI. L. Rev. 1639 (2002).

7 See Saikrishna B. Prakash \& John C. Yoo, Questions for the Critics of Judicial Review, 72 Geo. Wash. L. Rev. 354 (2003).

8 Foreign Intelligence Surveillance Act, 50 U.S.C. $\S 1801-1862$ (2000). 
peratives of conducting war. Thus, judicial review may apply to domestic wartime measures, but in a manner that provides options to the political branches for the conduct of the war, rather than simply serving as a negative check on government action.

I.

After the September 11, 2001 terrorist attacks, the United States went to war against the al Qaeda terrorist organization. On that day, al Qaeda operatives hijacked four commercial airliners and used them as guided missiles against the World Trade Towers in New York City and the Pentagon in the nation's capital. Resisting passengers brought down a fourth plane in Pennsylvania that appears to have been headed toward either the Capitol or the White House. The attacks caused about three thousand deaths, disrupted air traffic and communications within the United States, and caused the economy billions of dollars in losses. Both the President and Congress have agreed these attacks marked the beginning of an armed conflict between the United States and the al Qaeda terrorist network. ${ }^{9}$ Indeed, al Qaeda's September 11 attacks amounted to a classic decapitation strike designed to eliminate the political, military, and financial leadership of the country.

The unconventional nature of the war, and of the enemy, has called upon the United States government to undertake a full spectrum of domestic and international responses. Al Qaeda has both taken to the battlefield against the United States in somewhat conventional warfare, and sought to introduce covert cells of operatives into the United States to carry out surprise attacks on civilians. It does not seek to defend or acquire any specific territory, and its personnel, material, and leadership move through the open channels of the international economy. In previous modern American conflicts, hostilities were limited to a foreign battlefield while the United States' home front remained safe behind two oceans. In this conflict, the battlefield can occur anywhere, and there can be no strict division between the front and home. Nonetheless, an important dimension of the conflict has been the war abroad, in which the U.S. Armed Forces and the intelligence agencies have played an offensive role aimed at destroying the terrorist network. In October 2001, the United States launched a military campaign in Afghanistan that, within a few short weeks, rooted out al Qaeda from its bases and removed from power the Taliban militia that had harbored it. ${ }^{10}$ Subsequently, the United States conducted operations against al Qaeda terrorists in other parts of the world, such as the Philippines, Yemen, and parts of Africa. It has detained hundreds of al Qaeda and Taliban fighters at the Naval Base in Guantanamo Bay, Cuba. In March 2003, motivated in part by Iraq's suspected links to terrorist groups generally and al Qaeda specifically, the

9 See Authorization for Use of Military Force, Pub. L. No. 107-40, 115 Stat. 224 (2001); President's Military Order of November 13, 2001, Detention, Treatment, and Trial of Certain Non-Citizens in the War Against Terrorism, 66 Fed. Reg. 57,833, 57,833 (Nov. 16, 2001).

10 For an earlier discussion of the legal issues surrounding the Afghanistan war, see Robert J. Delahunty \& John C. Yoo, The President's Constitutional Authority to Conduct Military Operations Against Terrorist Organizations and the Nations That Harbor or Support Them, 25 HaRv. J.L. \& PuB. POL'y 487 (2002). 
United States and its allies invaded Iraq and removed Saddam Hussein from power. ${ }^{11}$

But unlike previous conflicts, the war against al Qaeda also has a significant domestic dimension. Al Qaeda operatives launched the initial salvo against the United States from within the United States. Al Qaeda shows no lessening in its efforts to pull off another attack within the United States on the scale of September 11. The Justice Department has discovered Al Qaeda cells in cities such as Buffalo, New York and Portland, Oregon; detained a resident alien who had intended to destroy the Brooklyn Bridge; and intercepted at least one American citizen in Chicago who had planned to explode a radiological dispersal device, known as a "dirty bomb," in a major American city. After the attacks, the federal government investigated and detained hundreds of illegal aliens within the United States with possible links to the terrorists. Many were deported. Two al Qaeda agents taken into custody within the United States have been designated as enemy combatants who are being detained without criminal charge until the end of the conflict. Congress enacted legislation, the USA Patriot Act, to enhance the powers of the Federal Bureau of Investigation ("FBI") and the intelligence community to defeat international terrorists within the United States, ${ }^{12}$ and created a new Department of Homeland Security to consolidate twenty-two separate domestic agencies with responsibilities for domestic security. ${ }^{13}$ After these legislative changes, the government engaged in an expanded surveillance effort to monitor the communications of terrorist targets under FISA.

\section{II.}

Examination of the military operations undertaken in the wake of the September 11 attacks demonstrates that the federal courts have no role in deciding whether the Congress or the president holds the power to begin wars. As I discuss in Part III, this stands in contrast with the role of the federal courts in domestic military and law enforcement operations in wartime. As I argue, constitutional text and structure dictate the absence of the courts in war matters abroad, and hence lie outside the scope of judicial review as recognized in Marbury v. Madison.

There are important textual and functional reasons why the courts should not inquire into the decision to initiate war. First, the Constitution vests all of the enumerated powers over war to the other two branches. Article II, Section 2 states that the "President shall be Commander in Chief of the Army and Navy of the United States, and of the Militia of the several States, when called into the actual Service of the United States." $14 \mathrm{He}$ is further vested with all of "the executive Power" and the duty to execute the

11 Of course, the primary justifications for the war in Iraq were Hussein's continuing possession of a weapons of mass destruction program and his flouting of United Nations Security Council Resolutions. See John Yoo, International Law and the War in Iraq, 97 AM. J. INT'L L. 563 (2003).

12 Uniting and Strengthening America by Providing Appropriate Tools Required to Intercept and Obstruct Terrorism (USA Patriot) Act of 2001, Pub. L. No. 107-56, 115 Stat. 272.

13 Exec. Order No. 13,228, 66 Fed. Reg. 51,812 (Oct. 8, 2001).

14 U.S. Consr. art. II, $\S 2$. 
laws. These powers give the president broad constitutional authority to use military force in response to threats to the national security and foreign policy of the United States. ${ }^{15}$ During the period leading up to the Constitution's ratification, the executive was understood to have the power to initiate hostilities and control conflict escalation. ${ }^{16}$

Congress has its own store of war powers. Article I grants Congress the authority "to declare War, grant Letters of Marque and Reprisal, and make Rules concerning Captures on Land and Water[,]" to raise, fund, and organize the military. ${ }^{17}$ Congress also enjoys other foreign affairs powers, such as the authority to regulate international commerce, to enact immigration laws, and to pass laws to punish piracy. ${ }^{18}$ While many have concluded that the power to declare war gives Congress the sole constitutional authority to decide whether to go to war, I have argued that the Constitution does not establish a specific legal process for beginning armed hostilities abroad. Rather, the two sets of war powers enumerated in Articles I and II permit the political branches to contest for primacy in war matters within a flexible system of allocated constitutional powers.

By contrast, the Constitution does create a detailed, finely-wrought procedure in which Congress plays the central role, namely lawmaking. If a bill does not undergo bicameralism and presentment, the courts can readily determine that it is not a law. ${ }^{19}$ In foreign affairs, however, the Constitution does not establish a mandatory, detailed, congressionally-driven procedure for taking action. Rather, the Constitution vests the two branches with different powers - the president as commander in chief, Congress with control over funding and declaring war-without requiring that they follow a specific process to make war. Thus, the president may use his commander-in-chief and executive powers to use military force to protect the nation, subject to congressional appropriation and control over domestic legislation. There is no role for judicial review because, unlike the legislative process, there is no clear, precise procedure that governs decisions on war. By establishing this framework, the framers expected that the process for making war would be more flexible and capable of quicker, more decisive action, than the legislative process.

Of course, a critic of this approach could respond that the area of war powers is textually no different than any other constitutional provision. There may be no specific constitutional authorization for judicial review over war powers, but there is also no explicit textual authorization for any other constitutional provision, yet we accept judicial review over most other consti-

15 See Loving v. United States, 517 U.S. 748, 776 (1996) (Scalia, J., concurring in part and concurring in judgment) (stating that the "inherent powers" of the commander in chief "are clearly extensive"); Johnson v. Eisentrager, 339 U.S. 763, 789 (1950) (noting that the president has authority to deploy United States armed forces "abroad or to any particular region"); Fleming v. Page, 50 U.S. (9 How.) 603, 615 (1850) ("As commander-in-chief, [the president] is authorized to direct the movements of the naval and military forces placed by law at his command, and to employ them in the manner he may deem most effectual ....").

16 See Yoo, Continuation of Politics, supra note 1, at 196-241.

17 U.S. Const. art. I, § 8 .

18 See id.

19 See INS v. Chadha, 462 U.S. 919 (1983). 
tutional questions. If that is the case, judicial review should extend to war powers just as it extends to the limits on Congress's interstate commerce powers or to the scope of the First Amendment. None of those clauses contains any special role for courts, so if judicial review extends to those areas it should reach war powers as well. Indeed, Professor Thomas Franck claims that Marbury v. Madison requires that the courts address war-powers disputes, and that judicial refusal to hear such cases has exempted the president from "the normal judicial umpiring process" that applies to his actions at home. ${ }^{20}$

This brings me to my second point. Generally, as I have argued in this symposium and in earlier work with Professor Prakash, the courts have the duty to refuse to enforce unconstitutional legislation-in other words, the power of judicial review. ${ }^{21}$ We have argued that the constitutional text, structure, and history dictate that the courts play this function, and have criticized others, such as Professors Kramer, Choper, and Wechsler, for arguing that the Constitution exempts whole categories of issues, such as federalism, from judicial review. We have argued that neither the constitutional text nor structure creates any broad categorical exceptions, such as federalism, to judicial review. A critic could argue that this view of judicial review is inconsistent with the argument that the courts are excluded from cases concerning the power to begin wars.

The question of the initiation of wars, however, is fundamentally different than that of judicial review over federalism questions. An initial and obvious point of distinction is that whether judicial review extends to a specific issue, such as the power to begin war, or the power to impeach, is a far narrower question than whether judicial review reaches all federalism questions or all separation-of-powers issues. The constitutional text or structure does not exclude such broad categories from judicial review. Unlike my colleague Jesse Choper, I have not yet reached the conclusion that all separation-ofpowers issues must remain immune from judicial review. ${ }^{22}$ Whether judicial review extends to a more discrete question, such as the initiation of war, will depend on the Constitution's specific textual and structural distribution of authority on that issue. If the power to determine a certain constitutional question has been committed solely to the authority of one or both of the other branches, then the political question doctrine in its most narrow, "classical" form will preclude the exercise of judicial review. While this essay is not the place to engage in an extended analysis of the appropriateness of the political question doctrine, it should not be forgotten that the very case cited for the creation of judicial review also first recognized what we today know as the political question doctrine. As Chief Justice Marshall wrote in Marbury v. Madison, "[b]y the constitution of the United States, the President is

20 Franck, supra note 3, at 4.

21 Saikrishna B. Prakash \& John C. Yoo, The Origins of Judicial Review, 70 U. CHI. L. Rev. 887 (2003); Saikrishna B. Prakash \& John C. Yoo, The Puzzling Persistence of ProcessBased Federalism Theories, 79 TEx. L. REv. 1459 (2001); John C. Yoo, The Judicial Safeguards of Federalism, 70 S. CAL. L. Rev. 1311 (1997). (1980).

22 Jesse Choper, Judicial Review and the National Political Process 295-96 
invested with certain important political powers, in the exercise of which he is to use his own discretion, and is accountable only to his country in his political character, and to his own conscience." 23 When these powers are involved

whatever opinion may be entertained of the manner in which executive discretion may be used, still there exists, and can exist, no power to control that discretion. The subjects are political. They respect the nation, not individual rights, and being entrusted to the executive, the decision of the executive is conclusive. ${ }^{24}$

Narrow application of the political question doctrine extends only to specific questions over which the Constitution has textually granted the final power of determination to the other branches; it does not imply the exclusion of judicial review over a whole category of cases. Impeachment illustrates this point. In Nixon $v$. United States, ${ }^{25}$ Judge Walter Nixon challenged the constitutionality of the Senate's decision to delegate the function of collecting evidence during the impeachment trial to a committee. The Court held the suit nonjusticiable because Article I gives the Senate "the sole Power to try all Impeachments," 26 which it read to give the power of decision on procedure and substance over impeachment to the Senate alone, without subsequent review by the courts. ${ }^{27}$ Finding that judicial review does not extend to impeachments, however, does not arise from a general refusal to adjudicate all separation-of-powers disputes. Rather, judicial review does not apply to the discrete issue of impeachment because of the Constitution's textual allocation of authority over it to the political branches. Courts can still decide questions about the independent counsel or the legislative veto, even if they cannot hear cases about impeachment.

Similar to the impeachment power, the Constitution has excluded the courts from the specific question of war by textually conferring the power of decision elsewhere. In cases challenging the constitutionality of presidential war making, plaintiffs argue that a current state of affairs constitutes a "war," and that Congress therefore must authorize the use of force before the president can begin hostilities. The Declare War Clause, however, vests in Congress the authority to declare, or, in other words to define, the legal relationship between the United States and another country. Like a declaratory judgment, a declaration of war represents the judgment of Congress that a certain state of relations between the United States and another country amounts to war under international law. ${ }^{28}$ At the time of the Constitution's ratification, a declaration of war itself was not linked to the start of military hostilities, and had generally fallen into disuse. ${ }^{29}$ A declaration of war established the formal, legal relationship between the two nations in conflict and defined the domestic legal status of certain wartime actions. A historically

23 Marbury v. Madison, 5 U.S. (1 Cranch) 137, 165-66 (1803).

24 Id. at 166.

25 Nixon v. United States, 506 U.S. 224 (1993).

26 U.S. Const. art. I, § 3, cl. 6.

27 Nixon, 506 U.S. at 230.

28 I have made this argument in more detail in Yoo, Continuation of Politics, supra note 1, at $204-08$.

29 Id. at 214-17. 
relevant example is the Declaration of Independence. The Declaration did not authorize hostilities with Great Britain, which had begun a year earlier, but instead recognized the legal independence and sovereignty of the former colonies and the state of hostilities with the mother country. ${ }^{30}$

Rather than giving the job of determining the international legal status of the United States to the courts, the Constitution vests in Congress the authority to determine whether the nation is legally at war. The power to declare war vests in Congress a juridical function of deciding whether a certain state of affairs constitutes a war for constitutional and legal purposes. When understood in this manner, an analysis that excludes judicial review over the initiation of war parallels the Court's reasoning in Nixon. With impeachment, the Constitution vests the juridical function of trying a government official in the Senate. Because the Constitution in these two cases has chosen to delegate a judicial function to the legislature, it makes no sense for the courts to review these decisions.

Even if courts were to address the merits of a war, they would not have available any constitutionally-compelled process to impose on the political branches. This is not to say that there are no "judicially discoverable and manageable standards for resolving"31 a dispute over war powers-the prudential version of the political question doctrine. A court could find a manageable standard by requiring that any use of force receive congressional authorization first. The point here is different. It is not that courts could not functionally create a principled standard capable of application in war powers, but rather that the Constitution itself demands none. This can be most clearly seen by comparing the structure of the war power to that of other governmental functions. When the Constitution creates a process that requires step-by-step approval by either the executive and legislative branches, it explicitly does so. Thus, with appointments and treaties, Article II, Section 2 clearly gives the president the initiative in appointments by beginning the process with the nomination of officers, and in treaty making, by allowing the president to negotiate treaties. ${ }^{32}$ But it also requires senatorial "advice and consent" before either process can be formally completed. ${ }^{33}$ With regard to statutes, Article I, Section 7 carefully delineates the qualified veto of the president, along with the process of House and Senate approval. ${ }^{34}$ It is relatively easy for courts to monitor compliance with lawmaking, treaty making, or appointing officers because the Constitution sets out clear rules to govern the process.

This stands in sharp contrast with the war power. The Constitution does not set out any process for going to war. Consider the questions that arise just over Congress's power to declare war. May the president sign a declaration of war? Must he? Must a declaration of war be proposed by the president? Is it subject to the bicameralism and presentment requirements of

30 See generally David Armitage, The Declaration of Independence and International Law, 59 WM. \& MARY Q. 39 (2002); Yoo, supra note 6, at 1671.

31 Baker v. Carr, 369 U.S. 186, 217 (1962).

32 U.S. Const. art. II, \& 2.

33 Id.

34 U.S. Const. art. I, $§ 7$. 
Article I, Section 7? May the president veto a declaration, and may Congress override it? Must a declaration precede hostilities? Can it come after hostilities? Could it never come at all, even though hostilities have proceeded? Can statutes serve as the functional equivalent of a declaration of war? The Constitution does not answer any of these questions because it fails to set out any specific process for going to war. Compare this to the Constitution's treatment of, for example, a revenue bill. Revenue bills must originate in the House, be approved by both House and Senate, and then signed by the president within a certain period of days. ${ }^{35}$ If he vetoes the bill, then a supermajority of Congress may enact it into law anyway. ${ }^{36}$ With regard to revenue bills, the Constitution establishes a specific process with clear rules and a step-by-step order, one which provides a rule of decision for courts to review. ${ }^{37}$ Even in areas where the Constitution has diluted the once sole executive authority over a certain subject, such as treaties or appointments, it still sets out a specific process. This is particularly telling because in regard to treaties and appointments, the Constitution allocates different roles to the president and Senate in exactly the way that many academics believe ought to apply to the war power. Yet, the Constitution is utterly silent when it comes to a process for war making.

With regard to the war power, there simply is no constitutionally-established process that the branches must follow. Rather, the Constitution allocates different war powers to the two branches without any specified process which determines their interaction. Article II, for example, vests full control of the United States military forces in the president. The power of the president is at its zenith under the Constitution when directing military operations of the armed forces because the power of commander in chief is assigned solely to the president. In The Prize Cases, ${ }^{38}$ for example, the Court explained that "[w]hether the President in fulfilling his duties as Commander in Chief[ ]" was justified in treating the southern States as belligerents and instituting a blockade, was a question "to be decided by him[.]"39 The Court could not question the merits of his decision, but must leave evaluation to "the political department of the Government to which this power was entrusted." 40 As the Court observed, the president enjoys full discretion in determining what level of force to use. ${ }^{41}$

35 Id.

36 Id.

37 See United States v. Munoz-Flores, 495 U.S. 385 (1990).

38 The Prize Cases, 67 U.S. (2 Black) 635 (1862).

39 Id. at 670 .

40 Id.

41 Id. ("He must determine what degree of force the crisis demands." (quotations omitted)); see Johnson v. Eisentrager, 339 U.S. 763, 789 (1949) ("Certainly it is not the function of the Judiciary to entertain private litigation-even by a citizen-which challenges the legality, the wisdom, or the propriety of the Commander-in-Chief in sending our armed forces abroad or to any particular region."); Chicago \& S. Air Lines v. Waterman S.S. Corp., 333 U.S. 103, 111 (1948) ("The President, both as Commander-in-Chief and as the Nation's organ for foreign affairs, has available intelligence services whose reports are not and ought not to be published to the world. It would be intolerable that courts, without the relevant information, should review and perhaps nullify actions of the Executive taken on information properly held secret."); Ramirez de Arellano v. Weinberger, 745 F.2d 1500, 1561 (D.C. Cir. 1984) (Scalia, J., dissenting), va- 
Congress has power over funding, and can thus deprive the president of any forces to command. Indeed, by setting the size, armament, and capabilities of the armed forces, Congress can determine the type, place, and duration of conflicts that the executive can wage. If Congress wants to prevent the president from waging offensive wars, or wars abroad, it can appropriate forces sufficient only for homeland and coastal defense, as it did for much of the early nineteenth century. Through the power to declare war, Congress can determine the legal status of presidentially-ordered military action. It could conceivably prevent the military from enjoying the benefits and protections of the laws of war, if it so chose. ${ }^{42}$

Viewing war powers in this manner explains why the political question doctrine applies to war but not perhaps to other separation-of-powers cases. Some have argued, such as my colleague Jesse Choper, that judicial review should not extend to separation-of-powers disputes because the executive and legislative branches have sufficient tools at their disposal to defend themselves from encroachments by the other branches. ${ }^{43}$ This observation concerning the distribution of authorities between the executive and legislative branches is no doubt true of war powers as it is of many other areas. Nonetheless, the Court has adjudicated many disputes between the president and Congress, with notable examples being the deficit reduction act in Bowsher $v$. Synar, ${ }^{44}$ the legislative veto in INS v. Chadha, ${ }^{45}$ the independent counsel law in Morrison v. Olson, ${ }^{46}$ and the U.S. Sentencing Commission in Mistretta $v$. United States. ${ }^{47}$ Judicial review may appropriately extend to such cases, however, when it does not to war powers. These cases involved areas in which the Constitution sets out a specific process for government action, such as the enactment of legislation or the appointment of federal officers. Courts must review whether the branches have followed the prescribed procedures to determine whether the final government actions themselves are valid. War powers would not fall into the same category, however, because there is no

cated by 471 U.S. 1113 (1985) (arguing that majority should deny injunctive relief to plaintiffs because it would require the president to take the court into its confidence regarding military operations); Ex parte Vallandigham, 28 F. Cas. 874, 922 (C.C.S.D. Ohio 1863) (No. 16,816) ("[U]nder this power where there is no express legislative declaration, the president is guided solely by his own judgment and discretion . . . ."); Hefleblower v. United States, $21 \mathrm{Ct}$. Cl. 228, 238 (1886) ("The responsibility of declaring what portions of the country were in insurrection and of declaring when the insurrection came to an end was accorded to the President; when he declared a portion of the country to be in insurrection the judiciary cannot try the issue and find the territory national; conversely, when the President declared the insurrection at an end in any portion of the country, the judiciary cannot try the issue and find the territory hostile."); $c f$. United States v. Chem. Found., Inc., 272 U.S. 1, 12 (1926) ("It was peculiarly within the province of the Commander-in-Chief to know the facts and to determine what disposition should be made of enemy properties in order effectively to carry on the war.").

42 Cf. Little v. Barreme, 6 U.S. (2 Cranch) 170, 177 (1804); Talbot v. Seeman, 5 U.S. (1 Cranch) 1, 7 (1801); Bas v. Tingy, 4 U.S. (4 Dall.) 37 (1800).

43 CHOPER, supra note 22, at 305-08.

44 Bowsher v. Synar, 478 U.S. 714 (1986).

45 INS v. Chadha, 462 U.S. 919 (1983).

46 Morrison v. Olsen, 487 U.S. 654 (1988).

47 Mistretta v. United States, 488 U.S. 361 (1989). 
constitutionally-mandated governmental process, and hence no room or need for judicial review.

Events since the September 11, 2001 attacks have borne out these principles. President Bush's decision to use force in Afghanistan does not appear to have been challenged in court. Such a lawsuit, if a member of Congress brought it, most likely would have failed on the merits. On September 18, 2001, Congress enacted a statute authorizing the President to use military force against "those nations, organizations, or persons he determines planned, authorized, committed, or aided the terrorist attacks that occurred on September 11, 2001, or harbored such organizations or persons[.]"48 The President responded to the September 11 attacks by ordering the use of force against al Qaeda and the Taliban regime that harbored it in Afghanistan. There could have been some challenge to the Afghanistan conflict: that the conflict was a "war" within the meaning of Article I, Section 8, and that therefore Congress must issue a declaration of war; a statutory authorization is no substitute. No court, however, appears to have been confronted with these arguments in any direct challenge to the legality of the conflict.

Instead, the legality of the war with al Qaeda has arisen in actions challenging the detention of Americans captured fighting in league with the enemy. In these cases, the courts have refused to second-guess whether the nation is at war, but instead have deferred to the judgment of the political branches. In Hamdi v. Rumsfeld, ${ }^{49}$ Yaser Esam Hamdi, who was born in Louisiana but grew up in Saudi Arabia, was captured in Afghanistan fighting on the side of the Taliban militia. Hamdi's father, acting as his next friend, filed a petition for a writ of habeas corpus seeking his release because he was not held on criminal charges. ${ }^{50}$ In dismissing the writ, Judge Wilkinson, writing for a unanimous panel in the United States Court of Appeals for the Fourth Circuit, did not question whether the United States was in a state of armed conflict in Afghanistan, nor whether that war was properly authorized under the Constitution. ${ }^{51}$ Indeed, the court emphasized that its role was limited to reviewing whether the executive branch had properly classified Hamdi as an enemy combatant, under the standards set out by Ex Parte Quirin, and hence could be detained under the laws of war until the end of the conflict. As Judge Wilkinson wrote, "the political branches are best positioned to comprehend this global war in its full context, and neither the absence of set-piece battles nor the intervals of calm between terrorist assaults suffice to nullify the warmaking authority entrusted to the executive and legislative branches[.]"52 The Fourth Circuit limited the scope of its review not to whether the war was properly begun, which was a decision for the political branches, but to the legal ramifications of the decision to go to war. ${ }^{53}$

48 Authorization for Use of Military Force, Pub. L. No. 107-40, 115 Stat. 224 (2001).

49 Hamdi v. Rumsfeld, 316 F.3d 450, 460 (4th Cir.), en banc reh'g denied, 337 F.3d 335 (4th Cir. 2003); Hamdi v. Rumsfeld, 296 F.3d 278, 280 (4th Cir. 2002); Hamdi v. Rumsfeld, 294 F.3d 598, 601 (4th Cir. 2002).

50 Hamdi, 316 F.3d at 450.

51 Id.

52 Id. at 464 (citations omitted).

53 See id. In Padilla v. Bush, Judge Mukasey of the Southern District of New York, review- 
A similar result was obtained in the lawsuits arising out of the detentions of captured alien enemy combatants at Guantanamo Bay. In two separate actions, those representing (or claiming to represent) aliens captured in Afghanistan and held by the military at the naval station at Guantanamo Bay filed petitions for writs of habeas corpus. ${ }^{54}$ In one case that lawyers and clergy brought, the United States Court of Appeals for the Ninth Circuit dismissed the petition for lack of standing, because none of the plaintiffs could show injury in fact or any actual relationship with the detainees. ${ }^{55}$ In the second lawsuit that relatives of some of the detainees brought, however, standing was not a barrier. ${ }^{56}$ Writing for a unanimous panel, Judge Randolph dismissed the case for lack of jurisdiction. ${ }^{57}$ He relied upon Johnson v. Eisentrager, ${ }^{58}$ which had held in the aftermath of World War II that German prisoners of war whom the military held abroad had no constitutional rights against the federal government and no ability to seek a writ of habeas corpus: 59

[T]he Guantanamo detainees have much in common with the German prisoners in Eisentrager. They too are aliens, they too were captured during military operations, they were in a foreign country when captured, they are now abroad, they are in the custody of the American military, and they have never had any presence in the United States. ${ }^{60}$

Following the logic of cases subsequent to Eisentrager, most notably United States v. Verdugo-Urquidez,${ }^{61}$ the United States Court of Appeals for the District of Columbia Circuit ("D.C. Circuit") concluded that no court could exercise jurisdiction over the detainees, "even if they have not been adjudicated enemies of the United States[,]" simply because they were aliens held outside the territorial United States. ${ }^{62}$ Again, the court did not question whether a state of war had begun, or whether the government had chosen war in the appropriate manner, but instead focused on the legal ramifications of those decisions as made by the political branches.

Unlike the conflict in Afghanistan, the war in Iraq prompted a more direct challenge to the manner in which the political branches decided to wage war. Like the Afghanistan conflict, Congress enacted legislation supporting the President's authority to use force in Iraq. In an October 2002 joint resolution, Congress authorized the President to use force against Iraq to enforce United Nations Security Council resolutions and to protect the

ing the detention of Jose Padilla, similarly concluded that the decision whether the United States was in a legal state of armed conflict rested wholly with the president, and was not an issue fit for judicial review. Padilla v. Bush, 233 F. Supp. 2d 564, 589 (S.D.N.Y. 2002).

54 Al Odah v. United States, 321 F.3d 1134 (D.C. Cir. 2003); Coalition of Clergy v. Bush, 310 F.3d 1153 (9th Cir. 2002).

55 Coalition of Clergy, 310 F.3d at 1162-64.

56 Al Odah, 321 F.3d at $1137-38$.

57 Id. at 1141.

58 Johnson v. Eisentrager, 339 U.S. 763 (1950).

59 Id.

60 Al Odah, 321 F.3d at 1140.

61 United States v. Verdugo-Urquidez, 494 U.S. 259, 273 (1990).

62 Al Odah, 321 F.3d at 1141. 
national security of the United States. ${ }^{63}$ Nonetheless, military personnel and members of the House of Representatives brought suit claiming that an invasion would violate the resolution and that Congress had unconstitutionally delegated its power to declare war. ${ }^{64}$ Finding that the case was unripe, the United States Court of Appeals for the First Circuit dismissed the case. ${ }^{65}$ Key to its holding was that even if an invasion were to occur, jurisdiction would depend on whether Congress took action to oppose the President, and thus created a ripe constitutional confrontation. ${ }^{66}$ In this respect, the First Circuit did not venture as far as other courts, such as the D.C. Circuit, which have suggested that interbranch disputes over war powers would be completely precluded from judicial review. ${ }^{67}$ In any event, the First Circuit, like every court confronted by an interbranch dispute over war powers, declined to reach the merits.

To be sure, this model of war powers may not appeal to everyone, especially those unconvinced by reliance on the original understanding or arguments based solely on the constitutional text and structure. At the very least, however, this Part demonstrates that original-understanding arguments do not support the notion that the Constitution requires a system in which Congress authorizes all wars ex ante. If we are left without a compelling textual or structural argument either, then a purely functional approach is left in the same position as the conclusion reached in this article: that the Constitution leaves the arrangement of the war powers up to the political branches. It would be difficult for a functionalist to argue that a different result ought to obtain than the war powers system we have today, in which the president initiates war, Congress funds it, and the courts remain aloof. The war powers system that has prevailed since the end of World War II, if not before, represents the consistent judgments of presidents, congressmen, and judges for more than fifty years about the best way to structure war powers. A functionalist would have no better information about the most effective institutional design for war powers than that available to the political branches themselves; certainly no court would have any better information. In light of that gap in information, a functionalist ought to defer to the institutional choice of the political branches. Someone moved by the historical, textual, and structural arguments made here, of course, would also accept historical practice, so long as it falls within the broad range of possible war-making systems permitted by the interaction of the branches' core powers.

The Bush administration's decision to seek congressional authorization for the wars in Afghanistan and Iraq would not disrupt this convergence. For a functionalist, 2001 and 2003 may mark the beginning of a new practice in which presidents turn to ex ante congressional authorization before using force. A return of formal congressional participation may become the norm

63 Authorization for Use of Military Force Against Iraq Resolution of 2002, 50 U.S.C.A. $\$ 1541$ (West Supp. 2003).

64 John Doe I v. Bush, 323 F.3d 133 (1st Cir. 2003).

65 Id. at $137-39$.

66 Id. at 139.

67 See, e.g., Campbell v. Clinton, 203 F.3d 19, 24-28 (D.C. Cir. 2000) (Silberman, J., concurring). 
because of the unique challenges created by the war on terrorism, which spans both foreign and domestic battlefields, and the enormous resources needed for the war in Iraq. It would represent the best judgment of the political branches that a Congress-first institutional design better suits the types of undertakings posed by the war on terrorism. If one believes, as I do, that the constitutional text, structure, and history permit a variety of different warmaking processes, this practice certainly falls within the range in which the Constitution permits.

\section{III.}

The exclusion of judicial review from the decision for war does not exclude the courts completely from reviewing the prosecution of war. When the war effort involves domestic affairs or, unfortunately, operations within the territorial United States, the political branches may call upon the courts to play a role. When it comes to war, the federal courts in their own way can serve as a weapon against a national enemy. This is illustrated by the current war against the al Qaeda terrorist network, which launched its deadliest and most successful attack directly on American soil, a feat it appears determined to repeat. First, as in the Civil War and World War II, American citizens have joined the enemy and returned to attack the United States. Their capture and detention may require the federal courts to review the circumstances of their capture and the legal basis for their continuing confinement. Second, efforts designed to frustrate and disrupt the al Qaeda network may prove most effective when using the tools and methods of law enforcement which may require the participation of the courts. In this Part, we explore the judicial role in the prosecution of war by examining the surveillance of terrorist suspects and their capture and detention.

Two points emerge from examining the role of the courts in the domestic front against al Qaeda. First, the judicial process can provide an alternate method for fighting terrorism that may prove more effective than regular, military efforts. For example, in some cases it may make more sense to use the familiar tools of law enforcement: a warrant to arrest and search, indictment and prosecution, and, eventually, trial. In other cases, however, it may prove more effective to follow the military model, which allows for the detention of enemy combatants without trial. Second, in order to perform this function the courts have developed a different standard of review that rejects the de novo standard applied to many questions raised during the regular operations of the domestic criminal justice system. Recent cases in the war against al Qaeda suggest that courts are following a deferential approach which, while not adopting the complete deference applied to the decision to initiate war, attempts to accommodate the imperatives of the war-fighting system so that effective means can be employed to combat al Qaeda at home.

\section{A. Surveillance}

Surveillance of terrorists could be undertaken within two distinct legal regimes. The first is the regular criminal justice system, in which the government may seek a warrant to conduct surveillance of a terrorist suspect's voice 
or electronic communications by presenting sufficient evidence of probable cause to an Article III judge. ${ }^{68}$ Surveillance undertaken in this manner would be no different than that used against organized crime groups or drug cartels operating within the United States. A second method, however, could present itself when terrorists undertake direct operations within the territorial United States. During wartime the military engages in searches and surveillance abroad without a warrant. We do not, for example, require the armed forces to seek a warrant when it conducts visual or electronic surveillance of enemy forces or of a battlefield, or when it searches buildings, houses, and vehicles for the enemy. ${ }^{69}$ Nor must military operations within the United States operate under a different rule. Were enemy forces to actually invade and operate on the territory of the United States, the Constitution would not require a search warrant for the military to conduct surveillance of the enemy. Every search or observation of confederate forces during the Civil War, for example, did not require a warrant. Therefore, if al Qaeda forces organize and carry out missions to attack civilian or military targets within the United States, government surveillance of terrorists would not be characterized as law enforcement so much as military operations. In such circumstances, when the government is not pursuing an ordinary criminal law enforcement objective, the Fourth Amendment requires no search warrant. ${ }^{70}$ Although the Supreme Court has not yet recognized them,$^{71}$ lower federal courts have held that searches undertaken to protect the national security are not subject to the warrant requirement in the context of domestic surveillance for counterintelligence purposes. ${ }^{72}$

Yet, searches authorized under the Fourth Amendment's Warrant Clause can have an important advantage over information gathered through the military's war-making function. The former can be used in the criminal justice system, and presumptively could be admitted in court. The latter, however, might not prove admissible in a civilian prosecution, as the searches might not have been undertaken on probable cause and would not have received ex ante judicial approval. In certain circumstances, the government may wish to incapacitate al Qaeda members through the use of the criminal justice system, rather than through capture and detention by the military. While conducting surveillance via the warrant process may prove the best way to permit the prosecution of terrorists, it has significant shortcomings in this context. A search warrant requires probable cause that "the evidence

6818 U.S.C. $\$ \S 2510-2522(2000)$.

69 See United States v. Verdugo-Urquidez, 494 U.S. 259, 273-75 (1990) (concluding that the Fourth Amendment did not protect nonresident aliens against unreasonable searches or seizures conducted outside the sovereign territory of the United States, because of serious detriment to armed forces abroad).

70 This conclusion is supported by the Supreme Court's recent "special needs" cases, which allow reasonable, warrantless searches for government needs that go beyond regular law enforcement. See Vernonia Sch. Dist. 47J v. Acton, 515 U.S. 646, 653 (1995) (random drugtesting of student athletes); Mich. Dep't of State Police v. Sitz, 496 U.S. 444, 447-55 (1990) (highway sobriety checkpoints); United States v. Martinez-Fuerte, 428 U.S. 543, 545 (1976) (border control checkpoints).

71 United States v. U.S. Dist. Court, 407 U.S. 297, 321-22 (1972).

72 United States v. Truong Dinh Hung, 629 F.2d 908, 913 (4th Cir. 1980). 
sought will aid in a particular apprehension or conviction' for a particular offense."73 Warrants, in other words, are usually granted on a probable cause standard that is retrospective: it is aimed at helping to solve a crime that has already taken place. A successful antiterrorism operation, however, should be prospective: it should prevent or disrupt the terrorist cell before it attacks. Surveillance will need to take place not because the government believes evidence of a past crime to be present, but because it suspects that certain individuals are linked to al Qaeda and may undertake future terrorist attacks.

This discussion may lead one to believe that the legal regime governing searches simply presents the government with a binary choice. It can operate within the civilian system of Fourth Amendment warrants and prosecution, or it can make use of the more flexible standards for military surveillance, forsaking the benefits of the criminal justice system. Congress, however, has called upon courts to develop a different approach that seeks to avoid this dilemma. In response to the revelation of warrantless national security searches, Congress enacted FISA in $1978 .{ }^{74}$ FISA created the Foreign Intelligence Surveillance Court ("FISC"), made up of Article III district judges drawn from around the country, which could issue a warrant to conduct a search for foreign intelligence information, and the Foreign Intelligence Surveillance Court of Review ("FISA Court of Review") to review applications that were denied by the FISC. ${ }^{75}$ The FISC may issue a search warrant if "there is probable cause to believe that ... the target of the electronic surveillance is a foreign power or an agent of a foreign power[.]" tion of foreign power includes international terrorist organizations. ${ }^{77}$ FISA permits an ex ante search warrant not based on a showing that a target was involved with criminal activity, but on probable cause that the target was linked to a terrorist organization. ${ }^{78}$ FISA proceedings are held ex parte, with only the government represented, in a closed hearing so that classified information can be discussed with the judges while protecting intelligence sources

73 Dalia v. United States, 441 U.S. 238, 255 (1979) (quoting Warden v. Hayden, 387 U.S. 294, 307 (1967)).

74 Foreign Intelligence Surveillance Act, 50 U.S.C. $\$ \S 1801-1862$ (2000). FISA and its legislative history are extensively analyzed in the first and only decision of the Foreign Intelligence Surveillance Court of Review ("FISA Court of Review"), composed of Judges Guy, Silberman, and Leavy. In re Sealed Case, 310 F.3d 717, 722-28 (Foreign Int. Surv. Ct. Rev. 2002).

7550 U.S.C. $\S 1803(\mathrm{a})-(\mathrm{b})$.

76 Id. $\$ 1805(\mathrm{a})(3)$.

77 FISA defines a foreign power, in part, as "a group engaged in international terrorism or activities in preparation therefor" and "a foreign-based political organization, not substantially composed of United States persons[.]" Id. § 1801(a)(4)-(5).

78 For targets who are United States persons, the standard is higher and approaches that of a Fourth Amendment warrant. See In re Sealed Case, 310 F.3d at 737-42. FISA requires that the information sought, if concerning a United States person, is related to the ability of the United States to protect against "(A) actual or potential attack or other grave hostile acts of a foreign power or an agent of a foreign power; (B) sabotage or international terrorism by a foreign power or an agent of a foreign power; or (C) clandestine intelligence activities by an intelligence service or network of a foreign power or by an agent of a foreign power[.]" 50 U.S.C. $\$ 1801(\mathrm{e})(1)$. As the FISA Court of Review observed, this showing is functionally similar to probable cause that the target is engaged in criminal activity. See In re Sealed Case, 310 F.3d at $737-41$. 
and methods. At the same time, the warrant permits a search whose fruits may be used in a subsequent prosecution.

FISA represents an effort by the political branches to promote judicial involvement in fighting threats to the national security. At the same time, it seeks to convince the courts to abandon the usual de novo review and adopt a standard of review that accommodates both national security needs and the option for use by law enforcement and prosecutors. It creates a statutory mechanism that grants national security warrants, but under a standard below that used for Fourth Amendment warrants, at least with regard to non-United States persons. Unlike military searches, however, the fruits of these searches will prove presumptively admissible in prosecutions. This allows the federal courts to offer another option to the political branches, that of prosecution and trial, in the war against the al Qaeda terrorist organization.

The courts have accepted this role. It appears that no court has found FISA to be unconstitutional. Initially, the courts erected a barrier between searches conducted for intelligence gathering and law enforcement by means of the "primary purpose" test, which required that the primary purpose of a FISA search be to collect foreign intelligence, rather than to engage in the investigation of ordinary crime. ${ }^{79}$ The FISC enforced this approach by limiting contact, and therefore preventing intelligence sharing, between intelligence and domestic law enforcement personnel on FISA investigations. ${ }^{80}$ The judiciary's wall of separation between foreign intelligence and law enforcement represented an attempt to contain the warrantless national security approach so as not to contaminate the criminal justice system, based as it is on warrants for the conduct of searches.

It is doubtful that the courts' interpretation of FISA was correct. Although FISA required a national security official to certify that "the purpose" of the surveillance was to collect foreign intelligence in order to receive a FISA warrant, ${ }^{81}$ this ultimately had little to do with the uses to which that intelligence was put. In other words, if the executive branch wanted to collect intelligence because it represented a foreign threat to national security, its purpose would be consistent with FISA even if were to decide that the most effective use of that information is criminal investigation and trial. Further, as the FISA Court of Review concluded, Congress's understanding when it enacted FISA was that criminal prosecution could help in the prevention of foreign threats to national security. ${ }^{82}$

In the wake of the September 11 attacks, this dichotomy fell apart. The terrorist attacks represented both a foreign threat to the national security and a violation of federal criminal laws against terrorism. The political branches

79 See In re Sealed Case, 310 F.3d at 725-27.

80 See id. at 720-21. As the FISA Court of Review observed, however, the idea for the wall of separation between intelligence and law enforcement appears to have originated in the Justice Department in 1995, apparently in response to circuit court decisions that demanded that FISA investigations be for the "primary purpose" of collecting foreign intelligence information. Id. at $727-36$.

8150 U.S.C. $\S 1804$.

82 In re Sealed Case, 310 F.3d at 724. 
sought again to convince the judiciary to develop a more flexible approach that would allow the government to benefit from the warrantless nature of national security searches. In the USA Patriot Act, Congress amended FISA to require that the government certify only that a "significant purpose" of the search is to collect foreign intelligence, clearly an attempt to reverse the judiciary's misinterpretation that FISA precludes cooperation between the foreign intelligence and law enforcement communities. ${ }^{83}$ The federal courts responded by eliminating the wall between foreign intelligence and law enforcement and moving the FISA system toward a more flexible approach. In its first decision ever, the FISA Court of Review reversed the FISC's attempt to keep law enforcement and foreign intelligence separate after September 11, although it indicated that this had returned FISA to its original meaning and that the USA Patriot Act amendment was unnecessary. ${ }^{84}$

Not only did the FISA Court of Review find that no such separation was warranted by FISA, but it suggested that FISA warrants themselves are not "warrants" in the Fourth Amendment sense, as they do not require a showing of probable cause of criminal activity. The FISA Court of Review found that, assuming that FISA warrants were not true warrants, they would still be constitutional under the Fourth Amendment because their use would fall within the exception for warrantless searches in cases where the government conducts the searches for important interests other than ordinary law enforcement (special needs cases). ${ }^{85}$ In other words, the FISA Court of Review found FISA searches to be constitutional as warrantless national security searches, yet also upheld FISA in such a way that would allow the fruits of the searches to be used in a criminal prosecution. Judicial review would extend to the searches, but deference to the political branches meant that they would enjoy more flexible constitutional standards.

\section{B. Enemy Combatants}

A similar choice between absolute deference to the political branches and full de novo judicial review has developed with regard to the detention of enemy combatants. The laws of war have long allowed nations to capture and detain members of the enemy armed forces. The detention of enemy combatants until the end of the conflict prevents them from rejoining the battle against a nation and allows the gathering of intelligence about the plans and activities of the enemy. As the laws of war also permit states at war to kill the enemy, the capture and detention of enemy combatants is a more humane outcome that reduces the death and suffering of the battlefield.

In the war against al Qaeda, the United States has encountered several categories of enemy combatants. These categories are more numerous than might usually be the case due to al Qaeda's stateless nature, which causes it to recruit operatives of different nationalities and to engage in offensive cov-

83 See 50 U.S.C. $\$ 1804(\mathrm{a})(7)(\mathrm{B}) ;$ see also id. $\$ 1806(\mathrm{k})(1)$.

84 In re Sealed Case, 310 F.3d at 736-46, rev'g In re All Matters Submitted to Foreign Intelligence Surveillance Court, 218 F. Supp. 2d 611 (Foreign Int. Surv. Ct. 2002).

85 In re Sealed Case, 310 F.3d at 736-46. 
ert activities throughout the world. The first category includes aliens captured and held outside the United States, such as the al Qaeda and Taliban fighters caught in Afghanistan and other operations abroad. The second category includes United States citizens who have joined al Qaeda and have been captured abroad. The third category includes aliens who have been detained within the United States, and the fourth category consists of United States persons, including both citizens and permanent resident aliens, who have been detained within the United States. The first category would include the detainees currently being held at the naval base in Guantanamo Bay, Cuba, none of whom are United States persons. ${ }^{86}$ The second category includes John Walker Lindh, captured in Afghanistan while fighting with the Taliban. Lindh was returned to the United States, stood trial for supporting a foreign terrorist organization, and reached a plea agreement for twenty years of imprisonment. ${ }^{87}$ It also includes Yaser Esam Hamdi, a Saudi Arabian citizen born in Louisiana, who was also captured in Afghanistan fighting with the Taliban. ${ }^{88}$ The third category includes Zacarias Moussaoui, who allegedly was part of the cell that carried out the September 11 hijackings and is currently on trial in Alexandria, Virginia for conspiracy to commit terrorist killings. ${ }^{89}$ The fourth includes Jose Padilla, an American citizen, captured attempting to enter Chicago from abroad with the purpose of furthering a plot to explode a radioactive dirty bomb. ${ }^{90}$

The role of the courts in reviewing the detention of enemy combatants demonstrates the tension between judicial review and the usual judicial deference to political wartime decisions. In the first category, that of alien enemy combatants captured and held abroad, the courts historically have refused to exercise judicial review. ${ }^{91}$ In Johnson $v$. Eisentrager, the Supreme Court refused to entertain a habeas petition brought by German World War II prisoners who challenged their trial and conviction by the military commission for war crimes. ${ }^{92}$ Finding that Article III courts had no jurisdiction over their petition, the Court observed that "these prisoners at no relevant time were within any territory over which the United States is sovereign, and the scenes of their offense, their capture, their trial and their punishment were all beyond the territorial jurisdiction of any court of the United States."93 Further, judicial deference to the decisions of the political branches was warranted because "trials would hamper the war effort and bring aid and

86 Their cases are discussed in Al Odah v. United States, 321 F.3d 1134 (D.C. Cir. 2003), and Coalition of Clergy v. Bush, 310 F.3d 1153 (9th Cir. 2002).

87 Various aspects of Lindh's prosecution are discussed in United States v. Lindh, $227 \mathrm{~F}$. Supp. 2d 565 (E.D. Va. 2002), United States v. Lindh, 212 F. Supp. 2 d 541 (E.D. Va. 2002), and United States v. Lindh, 198 F. Supp. 2d 739 (E.D. Va. 2002).

88 Hamdi's situation is discussed most recently in Hamdi v. Rumsfeld, 337 F.3d 335 (4th Cir. 2003) (denial of petition for rehearing en banc).

89 United States v. Moussaoui, 333 F.3d 509 (4th Cir.), reh'g denied, 336 F.3d 279 (4th Cir. 2003).

90 Padilla v. Bush, 233 F. Supp. 2d 564 (S.D.N.Y. 2002).

91 Johnson v. Eisentrager, 339 U.S. 763 (1950).

92 Id. at $766-68$.

93 Id. at 778 . 
comfort to the enemy." 94 Judicial proceedings would engender a "conflict between judicial and military opinion," interfere with military operations by recalling personnel to testify, and "would diminish the prestige of" a field commander called "to account in his own civil courts" and would "divert his efforts and attention from the military offensive abroad to the legal defensive at home."95 In such cases, just as with the initiation of hostilities, judicial review has no role, as such decisions have been vested in the political branches and any exercise of jurisdiction would interfere with the conduct of military operations.

In $A l$ Odah $v$. United States, ${ }^{96}$ a unanimous panel of the D.C. Circuit agreed that Eisentrager dictated that the al Qaeda and Taliban fighters held at Guantanamo Bay also remained beyond the reach of the Great Writ. Finding that the naval base in Cuba lay outside the territorial jurisdiction of the United States, ${ }^{97}$ Judge Randolph wrote for the panel that the petitioners, as aliens outside the United States with no constitutional rights, could not seek judicial review. As Judge Randolph concluded, "[i]f the Constitution does not entitle the detainees to due process, and it does not, they cannot invoke the jurisdiction of our courts to test the constitutionality or the legality of restraints on their liberty." 98 This result reaffirms the judiciary's historical refusal to interfere in the decisions to initiate and conduct military hostilities, which the Constitution vests in the political branches.

The other three categories of enemy combatants, however, do not fall within Johnson v. Eisentrager's rule. Americans detained abroad can seek judicial review of their detention, ${ }^{99}$ and there is no question that the writ of habeas corpus extends to both citizens and noncitizens detained within the territory of the United States. While jurisdiction may exist, however, it is not clear what standards the courts will apply to review the government's determination that a petitioner is an enemy combatant. In both the Hamdi and Padilla cases, no party has challenged the federal courts' authority to decide the legal questions-the legal standard for status as an enemy combatantde novo. What remains at issue, however, is whether the federal courts must accept the facts as the executive branch found them, and whether it must adopt a deferential approach to the government's application of the law to those facts. In examining how the courts so far have wrestled with these questions, we can see that they are developing an approach, similar to the one in the surveillance context, which preserves judicial review while providing the political branches with sufficient flexibility to perform their constitutional functions of fighting and winning a war.

Before discussing the level of scrutiny, we should first make clear the legal context: the detention of enemy combatants regardless of citizenship or location of capture. Usually, in the American experience, enemy combatants have been captured and detained abroad during combat on foreign battle-

94 Id. at 779 .

95 Id.

96 Al Odah v. United States, 321 F.3d 1134 (D.C. Cir. 2003).

97 Id. at $1142-44$.

98 Id. at 1141.

99 See Reid v. Covert, 354 U.S. 1, 8-10 (1957) (plurality opinion). 
fields with the U.S. Armed Forces. The unconventional nature of the war with al Qaeda-its members are drawn from many nations, including the United States, and its operatives might be caught anywhere, including within the United States-means that the government may capture and detain enemy combatants within the United States itself. While unusual, this is not unprecedented. During the Civil War, for example, virtually every captured enemy combatant was an American citizen. They did not fall within the Bill of Rights protections for criminal defendants because they were not detained as part of the criminal justice process; they were detained in combat. ${ }^{100}$ To be sure, there are limits to the executive's authority to detain American citizens as enemy combatants. In Ex Parte Milligan, ${ }^{101}$ the Supreme Court ordered the release of an American citizen who had plotted to attack military installations and was detained by Union military authorities while "the courts [were] open and their process unobstructed." 102 Milligan, however, had been captured well away from the front, had never communicated with the enemy, and at best was merely a sympathizer with the Confederate cause. ${ }^{103}$ During World War II, the Supreme Court in Ex Parte Quirin ${ }^{104}$ narrowed Milligan's holding to cases in which the citizen had not associated in any way with the enemy armed forces. ${ }^{105}$ Quirin upheld the government's trial by military commission of Nazi saboteurs who had infiltrated covertly into the United States and were caught by the FBI. ${ }^{106}$ Two of the Nazi saboteurs appeared to be American citizens, but the Court brushed aside this fact, holding that the government could detain enemy combatants regardless of whether they were citizens or not: "Citizenship in the United States of an enemy belligerent does not relieve him of the consequences of a belligerency which is unlawful[.]"107 Milligan was not an enemy combatant subject to detention under the laws of war because he, "not being a part of or associated with the armed forces of the enemy, was a non-belligerent[.]"108 Once properly designated an enemy belligerent, however, even an American citizen may be detained and tried by military commission, rather than enjoy the benefits of the criminal procedures established by the Bill of Rights and subject to judicial review.

In reviewing the legal question of the president's power de novo, both the Hamdi and Padilla courts agreed that the president's war power to detain enemy combatants extended to citizens. As noted earlier, both courts accepted, without question, the political branches' decision that the conflict with al Qaeda was a war, and both found no quarrel with the conclusion that this state of war enabled the President to detain members of the enemy pursuant to his war powers. In this respect, the courts have followed the historical practice of complete judicial deference on the question of going to war.

100 See William Whting, War Powers Under the Constitution of the United STATEs 44-46 (10th ed. 1864).

101 Ex parte Milligan, 71 U.S. (4 Wall.) 2 (1866).

102 Id. at 121.

103 Id. at 131.

104 Ex parte Quirin, 317 U.S. 1 (1942).

$105 \mathrm{Id}$. at 45.

$106 I d$. at $20-23,48$.

107 Id. at 37.

108 Id. at 45 . 
The crucial question remains, however, what standard of review will the courts exercise over the facts of an individual detention and the application of law to those facts. In a regular habeas case, for example, a federal court reviewing a purely executive detention (rather than, as is usually the case, detention and conviction of a criminal defendant by the state courts) might exercise de novo review of the facts. If the executive claimed, for example, that an individual had to be detained because he posed an imminent threat to public safety, ${ }^{109}$ a judge might feel it necessary to examine witnesses in court and to review directly the records of the detention. In wartime, however, as Johnson $v$. Eisentrager so vividly explained, such judicial intrusiveness could threaten to interfere with ongoing military operations. It is worth quoting the relevant passage from Eisentrager at length:

The writ, since it is held to be a matter of right, would be equally available to enemies during active hostilities as in the present twilight between war and peace. Such trials would hamper the war effort and bring aid and comfort to the enemy. They would diminish the prestige of our commanders, not only with enemies but with wavering neutrals. It would be difficult to devise a more effective fettering of a field commander than to allow the very enemies he is ordered to reduce to submission to call him to account in his own civil courts and divert his efforts and attention from the military offensive abroad to the legal defensive at home. Nor is it unlikely that the result of such enemy litigiousness would be a conflict between judicial and military opinion highly comforting to enemies of the United States. ${ }^{110}$

Add to these concerns the important military interest, only made more acute by the unconventional nature of the war with al Qaeda, of interrogating enemy combatants for information about coming attacks. Under this understanding of war, de novo judicial review threatens to undermine the very effectiveness of the military effort against al Qaeda. A habeas proceeding could become the forum for recalling commanders and intelligence operatives from the field into open court; disrupting overt and covert operations; revealing successful military tactics and methods; and forcing the military to shape its activities to the demands of the judicial process. Indeed, the discovery orders of the trial judge in Hamdi threatened to achieve exactly these results.

In Hamdi, Judge Wilkinson, writing for a unanimous Fourth Circuit panel, recognized the potentially conflicting approaches to judicial review in wartime. After reviewing the Constitution's allocation of war powers to the political branches and the functional superiority of the president and Congress.in waging war, Judge Wilkinson observed that "[i]n accordance with this constitutional text, the Supreme Court has shown great deference to the po-

109 See, e.g., United States v. Salerno, 481 U.S. 739, 748 (1987) ("[I]n times of war or insurrection, when society's interest is at its peak, the Government may detain individuals whom the government believes to be dangerous."); Moyer v. Peabody, 212 U.S. 78, 82-83 (1909) (governor's detention of individual because of insurrection).

110 Johnson v. Eisentrager, 339 U.S. 763, 779 (1950). 
litical branches when called upon to decide cases implicating sensitive matters of foreign policy, national security, or military affairs." 111 These interests are at their zenith when the president makes decisions with regard to the capture of enemy combatants in a zone of active hostilities. At the same time, however, Judge Wilkinson affirmed the judiciary's role in reviewing detentions by the government, even those that occur during wartime: "The duty of the judicial branch to protect our individual freedoms does not simply cease whenever our military forces are committed by the political branches to armed conflict." 112 In reviewing the district court's order for production of witnesses and documents, the Fourth Circuit rejected a de novo standard of review of the facts as too intrusive into the political branches' management of war. "The factual inquiry upon which Hamdi would lead us, if it did not entail disclosure of sensitive intelligence, might require an excavation of facts buried under the rubble of war. The cost of such an inquiry in terms of the efficiency and moral of American forces cannot be disregarded." 113

In deciding whether to accept the government's account of the facts, the court was confronted with an affidavit by Michael Mobbs, a Defense Department official, which outlined the basic circumstances of Hamdi's capture and activities. ${ }^{114}$ The court held that these statements were "sufficient to confirm that Hamdi's detention conforms with a legitimate exercise of the war powers given the executive by" the Constitution. ${ }^{115}$ The government further argued that no further factual inquiry was required, and suggested that the courts adopt a "some evidence" standard to govern review of enemy combatant determinations. ${ }^{116}$ In the immigration context, for example, courts have upheld deportation orders-another area of primary executive branch responsibility involving considerations of foreign affairs and national security-so long as "there was some evidence to support" the "factual determinations made by the Executive." 117 The Fourth Circuit ultimately found further review to be unnecessary due to the concession by Hamdi's counsel that Hamdi was captured in Afghanistan with a weapon fighting for the Taliban. ${ }^{118}$ The court found that these uncontroverted facts clearly satisfied the legal test for enemy combatant status, and the writ was dismissed.119

Jose Padilla's counsel, unlike Hamdi's, did not concede facts that showed her client to be a member of al Qaeda. As a result, Judge Mukasey of the Southern District of New York had to confront the standard of review question avoided by the Fourth Circuit. ${ }^{120}$ News coverage has focused on the court's order that Padilla be permitted access to a lawyer, which the govern-

111 Hamdi v. Rumsfeld, 316 F.3d 450, 463 (4th Cir. 2003) (quoting Hamdi v. Rumsfeld, 296 F.3d 278, 281 (4th Cir. 2002)).

112 Id. at 464.

$113 I d$. at 471.

114 Id. at 472.

115 Id. at 473.

116 Id. at $473-74$.

117 INS v. St. Cyr, 533 U.S. 289, 306 (2001); see also Eagles v. Samuels, 329 U.S. 304, 312

(1946); Fernandez v. Phillips, 268 U.S. 311, 312 (1925).

118 Hamdi, 316 F.3d at 473.

119 Id. at 476.

120 Padilla v. Bush, 233 F. Supp. 2d 564, 605-10 (S.D.N.Y. 2002). 
ment has appealed to the United States Court of Appeals for the Second Circuit. ${ }^{121}$ Despite finding that Padilla had no right to counsel in habeas proceedings, nor a Fifth or Sixth Amendment right to counsel due to the noncriminal nature of the proceedings, the court concluded that access to counsel was necessary in order to allow Padilla to present any facts that might controvert the government's case. ${ }^{122}$ This apparent defeat for the government notwithstanding, it is important to realize how much of the government's position Judge Mukasey accepted. Like the Fourth Circuit, this court deferred to the political branches' determination to wage war. It found that the president's war power included the authority to detain members of the enemy, including American citizens; that this power extended to the capture of al Qaeda operatives within the United States; and as a result, that enemy combatants could be detained until the end of the conflict without criminal charges. ${ }^{123}$

Most important, for our purposes, the court agreed that substantial deference was owed the political branches in the exercise of the war power:

The 'political branches,' when they make judgments on the exercise of war powers under Articles I and II, as both branches have here, need not submit those judgments to review by Article III courts. Rather, they are subject to the perhaps less didactic but nonetheless searching audit of the democratic process. ${ }^{124}$

As a result of the Constitution's division of authority over war, the court rejected the argument that it should conduct a de novo review of Padilla's association with al Qaeda. Instead, the court believed its inquiry was limited to "whether there is some evidence to support [the president's] conclusion that Padilla was, like the German saboteurs in Quirin, engaged in a mission against the United States on behalf of an enemy with whom the United States is at war[.]"125 Thus, the only setback for the government in its litigation over enemy combatants-and a limited setback at that-was the federal court's adoption of a deferential standard that accommodates judicial review while acknowledging the primacy of the political branches concerning the conduct of war.

In this respect, the Padilla court reflects the balance struck between judicial review and the imperatives and exigencies of war. Courts have refused to second-guess the determination of the political branches to go to war, and instead have limited the scope of their review to the domestic ramifications of the legal status of war. Thus, they have dismissed cases questioning the conduct of the war abroad. Even with domestic cases, such as those involving surveillance or detention of terrorists, the courts have exercised judicial review quite differently than the de novo review commonly seen in peacetime, nonforeign affairs cases. Instead, the courts have proven quite deferential to

\footnotetext{
$121 I d$. at 605.

122 Id . at 599-605.

123 Id. at 587-99.

124 Id. at 607.

125 Id. at 608.
} 
the political branches in a clear effort to accommodate judicial review to the compelling governmental interests in conducting and winning a war.

\section{Conclusion}

Whether the federal courts may refuse to enforce unconstitutional actions by the other branches of government is a question that has been with us since the origins of the Constitution. Recently, it has reappeared because of the Rehnquist Court's interest in federalism. This paper has explored judicial review's provenance in a wholly different area, that of the separation of powers generally, and war powers specifically. Here, the courts historically have refused to adjudicate disputes over which branch may initiate military hostilities abroad, a result produced by the Constitution's textual allocation of war powers to the political branches and its structural failure to define a specific process for war making. Nonetheless, courts continue to play a role in war by hearing cases involving the domestic ramifications of a decision that the United States is in a state of war. Yet, as we have seen with cases involving the surveillance and detention of terrorists, courts have adopted a deferential standard of scrutiny that provides the political branches with the flexibility to conduct war successfully.

By doing so, the exercise of judicial review is playing more than its usual role as a check and balance on the actions of the other branches. Rather, judicial review presents the president and Congress with new weapons with which to fight the war on terrorism. In the case of FISA surveillance, for example, deferential judicial review allows the executive branch to intercept terrorist communications under a standard similar to that which applies to military surveillance, all the while preserving the possibility of the use of the evidence in a federal prosecution. With its deferential review toward the detention of enemy combatants, federal courts not only provide the executive with a different way of holding terrorists, but they also present the option, perhaps, of later moving the detainees into the federal court system for prosecution. In both cases, the more deferential standard of scrutiny allows the political branches to undertake immediate wartime actions under the more flexible rules of the laws of war, without forsaking later use of the federal criminal justice system as means of sanctioning and incapacitating members of al Qaeda. By presenting more options to the war fighting branches of government, the courts act not merely as a traditional check on government, but as a potential weapon that can assist the United States' war on terrorism. 
The George Washington Law Review

HeinOnline -- 72 Geo. Wash. L. Rev. 452 2003-2004 